\title{
NUTRIENT CONTENTS AND PRODUCTION OF ROCKET AS AFFECTED BY NITROGEN CONCENTRATIONS IN THE NUTRITIVE SOLUTION
}

\author{
Rodrigo Luiz Cavarianni ${ }^{1}$; Arthur Bernardes Cecílio Filho²*; Jairo Osvaldo Cazetta ${ }^{3}$; André \\ May $^{4}$; Mariana Marotti Corradi ${ }^{5}$ \\ ${ }^{1}$ UNESP/FCAV - Programa de Pós-Graduação em Agronomia, Produção Vegetal. \\ ${ }^{2}$ UNESP/FCAV - Depto. Produção Vegetal, Via de Acesso Prof. Paulo Donatto Castellane, s/n -14884-900 - \\ Jaboticabal, SP - Brasil. \\ ${ }^{3}$ UNESP/FCAV - Depto. Tecnologia. \\ ${ }^{4}$ IAC - Centro de Horticultura, Av. Barão de Itapura 1481, C.P. 28 - 13001-970 - Campinas, SP - Brasil. \\ ${ }^{5}$ UNESP/FCAV - Graduação em Agronomia. \\ *Corresponding author <rutra@fcav.unesp.br>
}

\begin{abstract}
Empiricism in the use of nutrient solutions is frequent. Several times the same nutrient solution is used to grow different species based only on morphological similarities. This practice may lead to nutritional imbalances, affecting not only the production but also the quality of the product due to an accumulation of nitrate. An experiment under hydroponic conditions - the NFT system - was conducted with the aim of evaluating the effect of the concentration of nitrogen in the nutrient solution on the production and on the nutrient and nitrate contents of rocket (Eruca sativa) salad leaves. The experiment was carried out in spring 2003, in a randomized block design and in a $4 \times 3$ factorial design, with four replicates. Four nitrogen concentrations in the nutrient solution (60.8; 121.6; 182.5; $243.5 \mathrm{mg} \mathrm{L}^{-1}$ ) and three rocket salad cultivars (Cultivada, Folha Larga and Selvática) were evaluated. Cv. Cultivada produced the tallest plants and the highest leaf fresh fitomass, not differing from cv. 'Folha Larga' in the number of leaves, leaf nitrate content, root dry fitomass and root fresh fitomass. An increment in $\mathrm{NO}_{3}^{-}, \mathrm{N}, \mathrm{Ca}$ and $\mathrm{P}$ and a reduction in $\mathrm{Mg}, \mathrm{K}$ and $\mathrm{S}$ occurred when the concentration of $\mathrm{N}$ in the nutrient solution was increased. Cultivation of cv. Cultivada at the concentration of $93 \mathrm{mg} \mathrm{L}^{-1}$ is the most recommended as it provides the highest yield and low nitrate content.
\end{abstract}

Key words: Eruca sativa, Diplotaxis tenuifolia, hydroponic system, cultivar, mineral nutrition

\section{TEORES DE NUTRIENTES E PRODUÇÃO DE RÚCULA EM FUNÇÃO DAS CONCENTRAÇÕES DE NITROGÊNIO EM SOLUÇÃO NUTRITIVA}

RESUMO: O empirismo no uso das soluções nutritivas é freqüente. Muitas vezes a mesma solução nutritiva é usada para diferentes espécies baseando-se apenas em semelhanças morfológicas. No entanto esta situação pode proporcionar desequilíbrio nutricional prejudicando tanto a produção quanto a qualidade do produto face o acúmulo de nitrato. Foi conduzido um trabalho em sistema hidropônico - NFT, com o objetivo de avaliar o efeito da concentração de nitrogênio na solução nutritiva na produção, nos teores de nutrientes e de nitrato em folhas de rúcula (Eruca sativa). O trabalho foi conduzido na primavera de 2003. Foram avaliadas quatro concentrações de nitrogênio na solução nutritiva (60,8; 121,6; 182,5; 243,5 mg L ${ }^{-1}$ ) e três cultivares de rúcula (Cultivada, Folha Larga e Selvática), sob delineamento de blocos ao acaso, fatorial $4 \times 3$, com quatro repetições. A cv. Cultivada apresentou maior estatura e fitomassa fresca de folhas, não diferindo da 'Folha Larga' quanto a número de folhas, teor de nitrato nas folhas e fitomassa seca e fresca da raiz. Houve incremento de $\mathrm{NO}_{3}^{-}$, N, Ca e P e diminuição de Mg, K e S com o aumento da concentração de N na solução nutritiva. O cultivo da cv. Cultivada na concentração de $93 \mathrm{mg} \mathrm{L}^{-1}$ é a mais recomendada em função da maior produtividade e baixo teor de nitrato.

Palavras-chave: Eruca sativa, Diplotaxis tenuifolia, sistema hidropônico, cultivar, nutrição mineral.

\section{INTRODUCTION}

The hydroponic method of crop production has expanded significantly in recent years, largely due to the fact that it does not require any soil preparation and saves labor, with the possibility of increasing the 
number of yearly cycles (avoiding crop rotation) and added value of the product. In Brazil, the "Nutrient Film Technique” (NFT), a technique which involves a film of solution constantly flowing over the roots of the plants with the aid of a pump, is the most popular hydroponic method (Cavarianni, 2002). Among leafy vegetables for which this method of growth has been adopted, rocket has succeeded in increasing its market share, and from 1997 to 2003, in some regions of Brazil, its sale volume rose $78 \%$ (Purquerio, 2005). However, no studies on nutrient concentration in the nutrient solution for rocket grown hydroponically have been recorded in the Brazilian literature, which gives to current recommendations an empirical character. This condition may cause nutritional imbalances, thus affecting the development of the plant being grown (Furlani et al., 1999).

Normally, nitrogen is the nutrient with the highest concentration in nutrient solutions for leafy vegetables. In the plant structural function, $\mathrm{N}$ is a constituent of amino acids, proteins, nitrogenous bases, enzymes, pigments and secondary products, also having a role in the processes of ionic absorption, photosynthesis, respiration, synthesis, cell propagation and differentiation (Malavolta et al., 1997). Although it plays an important role in plant metabolism, an excess may lead to a reduction in the quality of the harvest for leafy vegetables in particular, as a result of the accumulation of nitrate. When ingested, nitrate is transformed into nitrite, which in association with amines may form carcinogenic compounds (Boink \& Speijers, 2001).

The aim of this study was to evaluate the effects of increasing nitrogen concentrations in the nutrient solution on rocket growth, yield, content of nutrients including nitrate.

\section{MATERIALAND METHODS}

The experiment was conducted from September 8 through October 29, 2003, under hydroponic

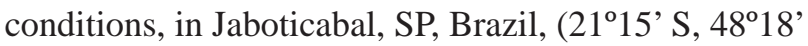
$\mathrm{W})$, at an altitude of 575 meters. The climate is classified as subtropical, with summer showers and a relatively dry winter (Volpe, 2006). The growth system used was the hydroponic "nutrient film technique" (NFT), with re-circulation of the nutrient solution. The experiment was carried out in an arch style greenhouse, $51 \mathrm{~m}$ long and $12.8 \mathrm{~m}$ wide, $3 \mathrm{~m}$ high at the sides, and with an air vent at the top. It was covered with a low-density polyethylene film, which was 150 mm thick and coated with an ultraviolet inhibitor. It had no lateral shade screens, but a $30 \%$ shade screen placed at the height of its arch was stretched over the culture whenever the air temperature in the greenhouse was above $30^{\circ} \mathrm{C}$.

The experiment was carried out in a randomized block design and a $4 \times 3$ factorial design, with four replicates, each parcel consisting of 40 plants $\left(0.48 \mathrm{~m}^{2}\right)$. The evaluated factors were the concentration of nitrogen in the nutrient solution $\left(\mathrm{N}_{1}-60.8 ; \mathrm{N}_{2}-121.6 ; \mathrm{N}_{3}\right.$ 182.5 and $\mathrm{N}_{4}-243.5 \mathrm{mg} \mathrm{L}^{-1}$ ) and three cultivars of rocket salad (Cultivada, Folha Larga and Selvática).

The nutrient solution was based on Furlani et al. (1999). Table 1 shows the concentrations for macronutrients and fertilizers used in each treatment. Ten $\%$ of total $\mathrm{N}$ in the solutions corresponded to ammonium. The concentrations of micronutrients used were $0.3 ; 0.02 ; 0.4 ; 0.06 ; 0.11$ and $2 \mathrm{mg} \mathrm{L}^{-1}$, respectively of $\mathrm{B}, \mathrm{Cu}, \mathrm{Mn}, \mathrm{Mo}, \mathrm{Zn}$ and Fe. EDDHMA was used as a chelating agent for iron.

Sowing was made using phenolic foam of 2 $\times 2 \times 2 \mathrm{~cm}$, which had been previously left in the sun and washed in running water, following its

Table 1 - Macronutrient concentrations, fertilizer and electrical conductivity in the nutrient solution (NS) in the NFT system.

\begin{tabular}{|c|c|c|c|c|c|c|c|c|c|c|c|}
\hline & $\mathrm{N}$ & $\mathrm{P}$ & $\mathrm{K}$ & $\mathrm{Ca}$ & & $\mathrm{Mg}$ & $\mathrm{Cl}$ & $S$ & & \multirow{2}{*}{\multicolumn{2}{|c|}{ Eletrical Condutivicty }} \\
\hline & \multicolumn{9}{|c|}{ - } & & \\
\hline NS 1 & 60.8 & 39.1 & 182.5 & 142.5 & & 40.0 & 153.4 & \multicolumn{2}{|l|}{98.3} & \multicolumn{2}{|c|}{2.0} \\
\hline NS2 & 121.6 & 39.1 & 182.5 & 142.5 & & 40.0 & 49.8 & 92.8 & & \multicolumn{2}{|r|}{2.2} \\
\hline NS3 & 182.5 & 39.1 & 182.5 & 142.5 & & 40.0 & 16.9 & 72.8 & & \multicolumn{2}{|r|}{2.3} \\
\hline NS4 & 243.5 & 39.1 & 182.5 & 142.5 & & 46.9 & - & 26.0 & & \multicolumn{2}{|r|}{2.5} \\
\hline & $\mathrm{KNO}_{3}$ & $\mathrm{~K}_{2} \mathrm{SO}_{4}$ & $\mathrm{Ca}\left(\mathrm{NO}_{3}\right)_{2}$ & $\mathrm{MgSO}_{4}$ & $\mathrm{CaCl}_{2}$ & $\mathrm{NH}_{4} \mathrm{NO}_{3}$ & MKP & $\left(\mathrm{NH}_{4}\right)_{2} \mathrm{SO}_{4}$ & $\mathrm{KCl}$ & $\mathrm{H}_{3} \mathrm{PO}_{4}$ & $\mathrm{Mg}\left(\mathrm{NO}_{3}\right)_{2}$ \\
\hline & - - - & 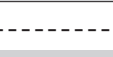 & 2 & $\ldots-\ldots g$ & $1000 \mathrm{dl}_{\mathrm{l}}$ & $m^{-3} \ldots \ldots$ & 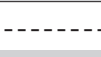 & 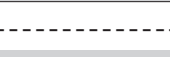 & -- & \multicolumn{2}{|c|}{-.- mL $1000 \mathrm{dm}^{-3}$-. } \\
\hline NS 1 & --- & 230 & 390 & 400 & 311 & --- & 170 & 30 & 75 & \multicolumn{2}{|c|}{$---\quad \quad--$} \\
\hline $\mathrm{NS} 2$ & 35 & 160 & 750 & 400 & --- & --- & 170 & 57 & 106 & \multicolumn{2}{|l|}{--} \\
\hline NS3 & 455 & --- & 750 & 400 & --- & --- & --- & 87 & 36 & \multicolumn{2}{|l|}{85} \\
\hline NS4 & 333 & 153 & 750 & --- & --- & 147 & --- & --- & --- & \multicolumn{2}{|l|}{85} \\
\hline
\end{tabular}


manufacturer's recommendation. Each cell received three seeds, which were planted $0.5 \mathrm{~cm}$ deep into the foam. The phenolic foam sheets were placed in the greenhouse and watered four times a day so that they were kept wet at all times. On day five after the sowing (DAS), plants were thinned to only one per cell. Thereafter seedlings were transplanted to the hydroponic channels, $5 \times 5 \mathrm{~cm}$ apart. At this growth phase the nutrient solution with the lowest nitrogen concentration (60.8 $\mathrm{mg} \mathrm{L}^{-1}$ ) was used.

When seedlings had four definite leaves, (25 DAS) they were transplanted to their final cultivation channels. These channels had a 3\% gradient for the solution to return to the tank; they were made of PVC tubes, $5 \mathrm{~m}$ long and with a diameter of $10 \mathrm{~cm}$, cut lengthwise and closed with expanded polystyrene, being $15 \mathrm{~cm}$ apart from center to center. The plants were planted $15 \times 8 \mathrm{~cm}$ apart.

The nutrient solution reservoir tanks were made of plastic containers of 40 liters, with lids. Their nutrient solution was intermittently aerated during the day by small compressors (60 $\mathrm{Hz}$ and $6 \mathrm{~W}$ ) with capacity for $4.5 \mathrm{~L} \mathrm{~min}^{-1}$, and pumped (pumps of $60 \mathrm{~Hz}$ and $32 \mathrm{~W}$ ) with a $0.8 \mathrm{~L} \mathrm{~min}^{-1}$ flow rate per channel.

The electrical conductivity was kept between 95 and $105 \%$ of the initial one by adding stock solution (Table 1), which was two-part concentrated with regard to its respective initial nutrient solution $\left(\mathrm{N}_{1}\right.$ to $\mathrm{N}_{4}$ ). The $\mathrm{pH}$ was kept between 5.5 and 6.5 with addition of sulfuric acid $\left(\mathrm{H}_{2} \mathrm{SO}_{4} 6 \mathrm{~N}\right)$. The nutrient solution was applied 10 minutes at 20-minute intervals from $6 \mathrm{~h} 00$ to $10 \mathrm{~h} 00$ am and from $4 \mathrm{~h} 00$ to $7 \mathrm{~h} 00 \mathrm{pm}$. From $10 \mathrm{~h} 00 \mathrm{am}$ to $4 \mathrm{~h} 00 \mathrm{pm}$ it was supplied for 10 minutes at 10 -minute intervals. During the night it was supplied for 10 minutes only once, at midnight.

Average maximum and minimum temperatures of 35.4 and $16.3^{\circ} \mathrm{C}$, respectively, and average maximum and minimum relative humidity of 93.0 and $27.6 \%$, respectively were recorded during the experiment. The data was obtained from a weather shelter located one meter above the ground at the center of the experimental area.

The plants were harvested on 10/29/2003, on day 26 after their final transplant. Data relating to stature and number of leaves was obtained one day before, without removing the plants from their cultivation channels. The characteristics evaluated were: Stature of plants (STA): the height of the largest, nonstretched leaf was measured starting at the cover (polystirene) of the cultivation channel, their cuttingpoint for sale, in ten plants chosen at random in each portion; Number of leaves (NL): for nonsenescent leaves, only; Fresh leaf fitomass (LFF) and root fitomass (RFF): between 6 and 7h00 a.m., five rocket plants from each parcel were chosen at random and cut three centimeters from their colon, and their roots separated from their leaves. They were immediately weighed on a digital scale. Leaf dry fitomass (LDF) and root dry fitomass (RDF): the leaves and roots of those five plants selected for evaluation of their fresh fitomass were washed with deionized water, placed in paper bags and dried in a drying chamber with forced air flow, at $65^{\circ} \mathrm{C}$, for 96 hours. They were then weighed, and their values expressed in g per plant; Leaf nutrient content: the dried leaves were ground in a Willey-type mill using a fine wire with 20 holes per inch (20 mesh), and the contents of N, P, K, Ca, Mg and $\mathrm{S}$ were determined using the methodology described by Bataglia et al. (1983); Leaf nitrate content: the nitrate content was determined in leaves collected at 8 h00 am. A newly matured leaf was collected from about four to six plants, wrapped in aluminum foil and promptly stored in liquid nitrogen. The samples were lyophilized and ground. The extract was obtained by moistening $100 \mathrm{mg}$ of the sample with $100 \mathrm{~mL}$ of ethyl alcohol, adding $2 \mathrm{~mL}$ of water at $70^{\circ} \mathrm{C}$, subjecting it to vacuum of $6 \mathrm{~mm} \mathrm{Hg}$ for a minute, with the mixture being kept in water bath for 20 minutes and centrifuged afterwards at $1800 \mathrm{xg}$. The nitrate content was determined using the methodology described by Cataldo et al. (1975).

Statistical analysis was performed through analysis of variance (test $\mathrm{F}$ at the $5 \%$ level of probability) following Banzatto \& Kronka (1995). The Origin $^{\circledR}$ program was also used to perform regressions at the $10 \%$ level of probability.

\section{RESULTS AND DISCUSSION}

NL, STA, RDF and LFF were not affected $(p>0.05)$ by the nitrogen concentration in the nutrient solution. Nitrogen concentration in the nutrient solution had a positive effect $(p<0.05)$ on LDF (Table $2)$. Nonetheless, STA, RDF, LFF and LDF were adjusted to the polynomial equations $(p<0.05)$ (Figures 1a, 1b, 1c, 1d). Similar responses were observed for LFF and LDF in relation to the increase in the $\mathrm{N}$ concentration in the nutrient solution. They both showed an increment when $\mathrm{N}$ was higher than $60 \mathrm{mg} \mathrm{L}^{-1}$, with their lowest amounts being obtained at the highest $\mathrm{N}$ concentration, that is, $243.5 \mathrm{mg} \mathrm{L}^{-1}$. Maximum LFF (15.8 g per plant) and LDF (1.63 g per plant) were calculated with an $\mathrm{N}$ estimative of 93 and $114 \mathrm{mg} \mathrm{L}^{-1}$, respectively, in the nutrient solution.

In relation to cultivar, Cultivada was superior to the other two cultivars for all characteristics, not differing from 'Folha Larga' in the number of leaves per plant, RDF or RFF (Table 3). Cv. Selvática did not 
Table 2 - F test and significance of evaluated characteristics.

\begin{tabular}{lccc}
\hline \multirow{2}{*}{ Characteristic } & \multicolumn{3}{c}{ Causes of variation } \\
\cline { 2 - 4 } & Nitrogen $(\mathrm{N})$ & Cultivars $(\mathrm{C})$ & Interaction $(\mathrm{N} \times \mathrm{C})$ \\
\hline Nitrate content & $32.17 * *$ & $6.52 * *$ & $0.98 \mathrm{~ns}$ \\
Stature & $1.31 \mathrm{~ns}$ & $191.91 * *$ & $1.7 \mathrm{~ns}$ \\
Number of leaves & $0.45 \mathrm{~ns}$ & $17.02 * *$ & $0.9 \mathrm{~ns}$ \\
Leaves dry fitomass & $3.81^{*}$ & $142.22^{* *}$ & $1.88 \mathrm{~ns}$ \\
Root dry fitomass & $1.09 \mathrm{~ns}$ & $118.86 * *$ & $0.97 \mathrm{~ns}$ \\
Leaves fresh fitomass & $2.62 \mathrm{~ns}$ & $92.8 * *$ & $0.92 \mathrm{~ns}$ \\
Root fresh fitomass & $1.9 \mathrm{~ns}$ & $142.77 * *$ & $0.87 \mathrm{~ns}$ \\
Nitrogen content & $54.07 * *$ & $18.98 * *$ & $0.74 \mathrm{~ns}$ \\
Phosphorus content & $1.75 \mathrm{~ns}$ & $7.76 * *$ & $0.63 \mathrm{~ns}$ \\
Potassium content & $1.22 \mathrm{~ns}$ & $6.65 * *$ & $0.40 \mathrm{~ns}$ \\
Calcium content & $7.80^{* *}$ & $2.65 \mathrm{~ns}$ & $0.67 \mathrm{~ns}$ \\
Magnesium content & $6.24 * *$ & $1.91 \mathrm{~ns}$ & $1.46 \mathrm{~ns}$ \\
Sulfur content & $11.48 * *$ & $7.53 * *$ & $3.03 *$ \\
\hline
\end{tabular}

ns - not significant $(p<0.05)$, *significant $(p<0.05),{ }^{* *}$ significant $(p<0.01)$.

Table 3 - Number of leaves (NL), plant stature (STA), root dry fitomass (RDF), root fresh fitomass (RFF), leaves dry fitomass (LDF) and leaves fresh fitomass (LFF), in rocket salad cultivars evaluated in the NFT system.

\begin{tabular}{|c|c|c|c|c|c|c|}
\hline Cultivars & NL & STA & RDF & RFF & LDF & LFF \\
\hline & Leaves per plant & $\mathrm{cm}$ & -........ & $\cdots-\cdots g$ & ant $\ldots-\ldots$ & - \\
\hline Cultivada & $11.45 \mathrm{a}$ & $16.59 \mathrm{a}$ & $0.8081 \mathrm{a}$ & $2.3594 \mathrm{a}$ & $16.8838 \mathrm{a}$ & $20.3825 \mathrm{a}$ \\
\hline Folha Larga & $10.47 \mathrm{a}$ & $13.90 \mathrm{~b}$ & $0.7019 \mathrm{a}$ & $1.7438 \mathrm{~b}$ & $14.7594 \mathrm{a}$ & $14.7600 \mathrm{~b}$ \\
\hline Selvática & $8.83 \mathrm{~b}$ & $6.55 \mathrm{c}$ & $0.1150 \mathrm{~b}$ & $0.4238 \mathrm{c}$ & $2.0088 \mathrm{~b}$ & $3.4944 \mathrm{c}$ \\
\hline
\end{tabular}

Means followed by the same letter within columns are not different (Tukey test, $p<0.05$ ).

perform well, its yield corresponding, on average, to $20 \%$ of those observed for the other two cultivars. This may be attributed to the fact that this cultivar did not adapt well to the climate of Jaboticabal, where the mean maximum temperature was $35.4^{\circ} \mathrm{C}$. In response to these high temperatures, cv. Selvática plants flowered prematurely, thus stopping their growth (STA, NL and accumulation of LDF and RDF). Though premature flowering was not observed in Cultivada and Folha Larga, the high temperatures may account for the fact that these two cultivars did not grow as well as expected. Santamaria et al. (2001) have verified that the rise in temperature from $10^{\circ} \mathrm{C}$ to $20^{\circ} \mathrm{C}$ results in a reduction in the rocket dry matter accumulation.

Cultivada and Folha Larga plants grew to a height of $16.6 \mathrm{~cm}$, which is below the Brazilian market standard ranging from 18 to $22 \mathrm{~cm}$ (Trani et al., 1994); height, in combination with visual aspect for rocket, are the characteristics which appeal to the vegetable consumer in Brazil . Small size of the plants contributed negatively to rocket salad yield. Cultivada, Folha Larga and Selvática yielded 1,815.6; 1,317.2 and $311.5 \mathrm{~g} \mathrm{~m}^{-2}$, respectively, which may be considered low. Trani et al. (1994) obtained $1,736 \mathrm{~g} \mathrm{~m}^{-2}$ of rocket salad under open-field cultivation.

With respect to leaf macronutrient contents, only nitrogen, calcium and magnesium were $(p<0.05)$ affected by $\mathrm{N}$ concentration in the nutrient solution. The cultivar factor affected the contents of N, P, K, and $S(p<0.05)$. Sulfur was affected $(p<0.05)$ by the interaction between the $\mathrm{N}$ concentration and cultivar factors (Table 2). Although their contents were not affected $(p>0.05)$ by $\mathrm{N}$ concentration, phosphorous and potassium were adjusted to the polynomial equations, $(p<0.1)$.

Increases in the $\mathrm{N}$ concentration in the nutrient solution up to $205 \mathrm{mg} \mathrm{L}^{-1}$ caused an increase in the leaf $\mathrm{N}$ content (Figure 2a). Increases of $\mathrm{N}$ content in the order of a $240 \%$ in the amount of $\mathrm{N}$ available in the nutrient solution (from 60 to $205 \mathrm{mg} \mathrm{L}^{-1}$ ) may be considered normal. Nevertheless, the corresponding increment in the leaf dry mass did not occur, which was reduced (Figure 1d) in spite of an increase in the $\mathrm{N}$ content in the LDF (Figure 2a).

The response of leaf calcium content to the increase in the nitrogen availability observed in this 


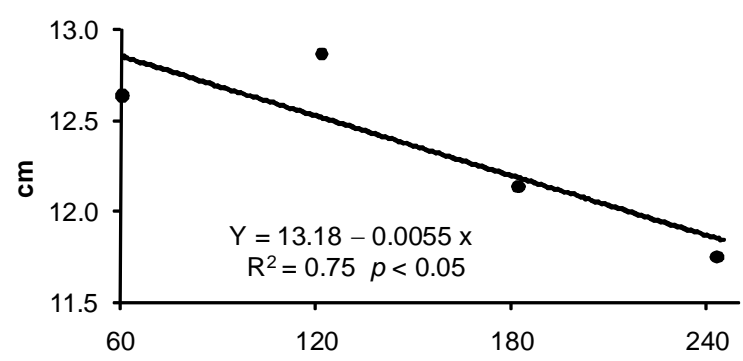

(a) Nitrogen in the nutrient solution $\left(\mathrm{mg} \mathrm{L}^{-1}\right)$

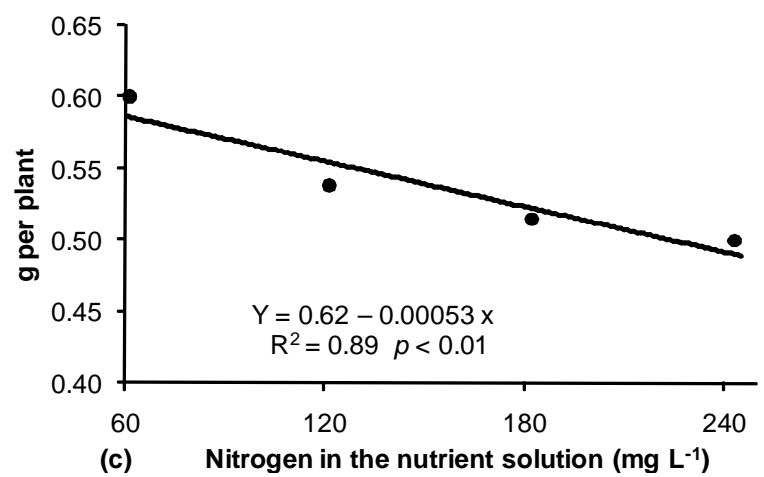

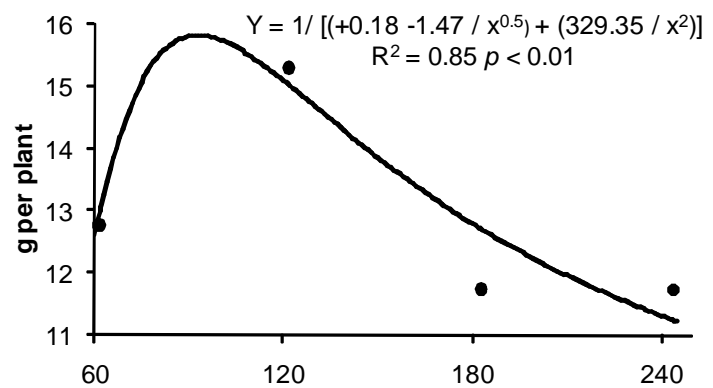

(b) Nitrogen in the nutrient solution ( $\left.\mathrm{mg} \mathrm{L}^{-1}\right)$

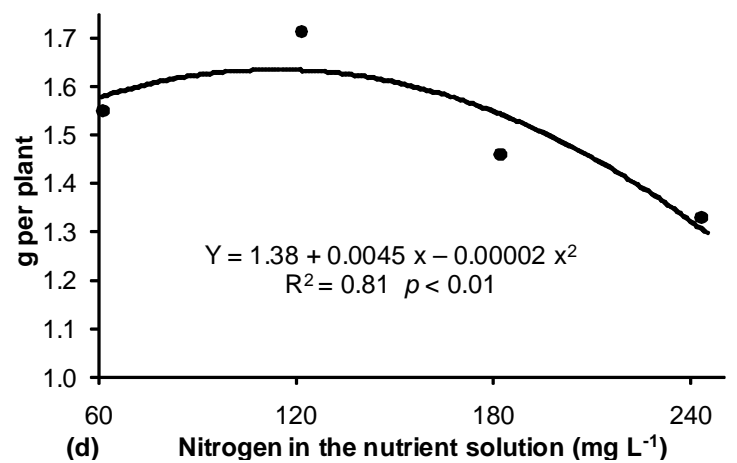

Figure 1 - Stature (a), leaves fresh fitomass (b), root dry fitomass (c) and leaves dry fitomass (d) of rocket salad plants for nitrogen concentration in the nutrient solution in the NFT system.

study (Figure 2b), was also reported by Purquerio (2005) for cultivars Folha Larga and Cultivada. This author observed a linear increase for calcium content from 18.9 to $24.6 \mathrm{~g} \mathrm{~kg}^{-1}$ in response to higher amounts of $\mathrm{N}$, from 0 to $240 \mathrm{~kg} \mathrm{ha}^{-1}$.

Contents of $\mathrm{Mg}$ and $\mathrm{K}$ in the plant were reduced with the increase of $\mathrm{N}$ in the nutrient solution (Figures 2c, 2d). K contents were higher than those of $\mathrm{N}$ in rocket salad dry mass up to $\mathrm{N}$ concentration of $165.5 \mathrm{mg} \mathrm{L}^{-1}$; when the reverse occurred. The theory of a $\mathrm{K}$ and $\mathrm{Mg}$ dilution effect with the increase in $\mathrm{N}$ in the nutrient solution does not seem to be well grounded since the aerial part dry mass of the rocket salad did not show any increment at $\mathrm{N}$ concentrations higher than $114 \mathrm{mg} \mathrm{L}^{-1}$ in the nutrient solution.

The $\mathrm{S}$ content in the rocket salad tissue was reduced in cultivars Cultivada and Folha Larga with the increase in $\mathrm{N}$ in the nutrient solution (Figure 2e). This probably occurred as a consequence of the lower concentration of sulfur in the solutions with higher concentrations of $\mathrm{N}$. This result may also have been favored by the ionic competition between $\mathrm{SO}_{4}^{2-}$ and $\mathrm{NO}_{3}^{-}$, which may also have helped the increase in phosphorus contents (Figure 3f) which is absorbed as $\mathrm{PO}_{4}^{2-}$.

The $\mathrm{N}: \mathrm{K}$ ratio in the nutrient solution providing maximum stature of plants and root dry fitomass was $0.33: 1$, that is, $60 \mathrm{mg} \mathrm{L}^{-1}$ of $\mathrm{N}$. For leaf dry mass and leaf fresh mass, these ratios were very close $0.62: 1$ and $0.51: 1$, respectively. Therefore, the N:K ra- tios found for LFF when compared to those obtained by other authors and for other crops, accentuate the empiricism used for recommending nutrient solutions without any distinction between leafy species since they are below those reported by Castellane \& Araújo (1994) for lettuce (0.66:1), and by Coelho (2002) for four cultivars of wild chicory (0.68:1 to 0.92:1).

Cultivada had the highest contents of $\mathrm{N}, \mathrm{K}$ and $\mathrm{S}$ in the aerial part dry matter, and did not differ from Folha Larga in its P content. The cultivars showed no difference in their $\mathrm{Ca}$ and $\mathrm{Mg}$ contents (Table 4). The poor adaptation of Selvática to the climate of Jaboticabal indicated by its low yield was not observed for its nutrient contents, being inferior to Folha Larga only in relation to phosphorus. It did not differ, though, from the other cultivars in regard to the other nutrients (Table 4).

The effect of the concentration of nitrogen in the nutrient solution and of the cultivars on the leaf nitrate content was significant $(p<0.01)$, whereas no effect of the interaction of the factors was observed $(p<0.05)$. An increment in the leaf nitrate content of the rocket salad cultivars was observed with the increase in the concentration of nitrogen in the nutrient solution (Figure 3). These results agree with those reported by Maynard et al. (1976); Graifenberg et al. (1993); Faquin et al. (1994), who stated that the nitrate content in the plant is largely dependent on its availability in the cultivation medium. 


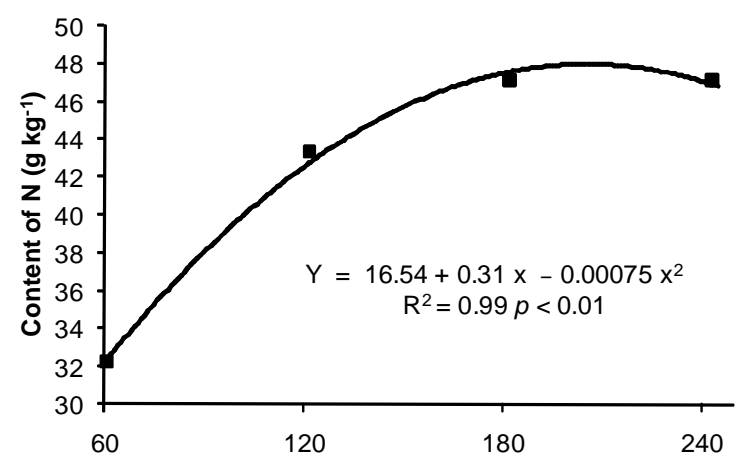

(a) Nitrogen in the nutrient solution $\left(\mathrm{mg} \mathrm{L}^{-1}\right)$

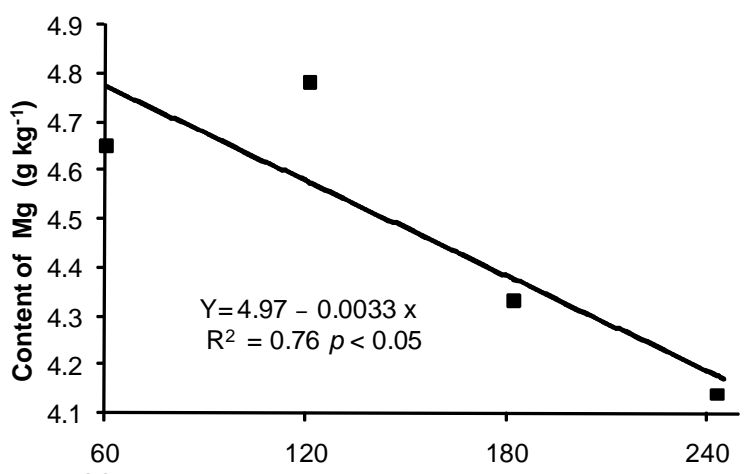

(c) Nitrogen in the nutrient solution $\left(\mathrm{mg} \mathrm{L}^{-1}\right)$

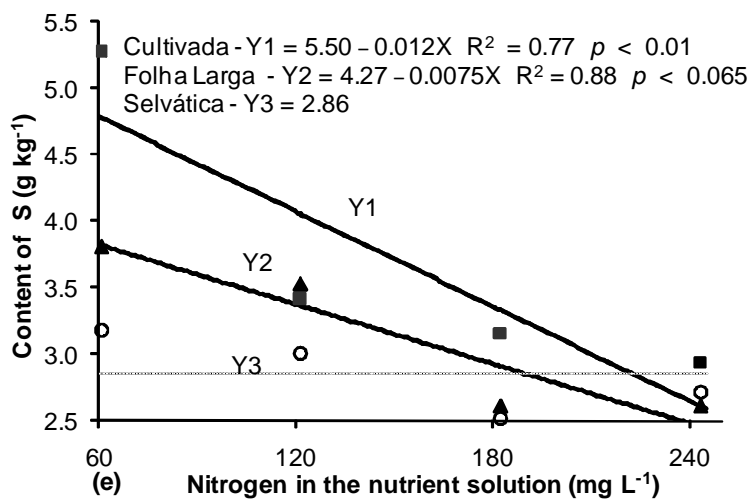

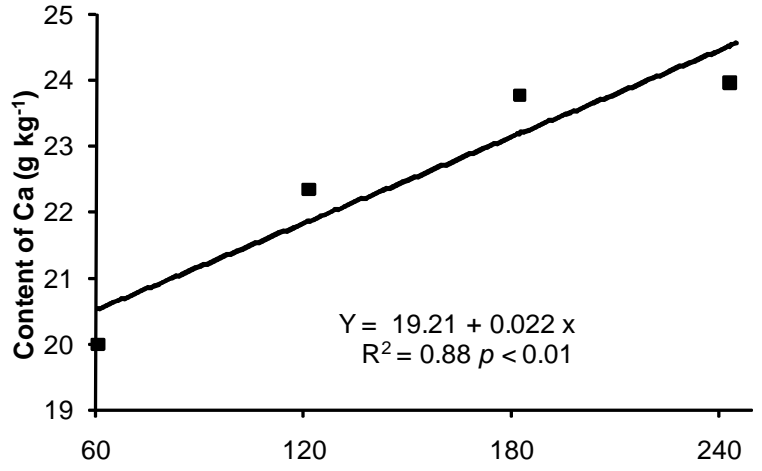

(b) Nitrogen in the nutrient solution $\left(\mathrm{mg} \mathrm{L}^{-1}\right)$
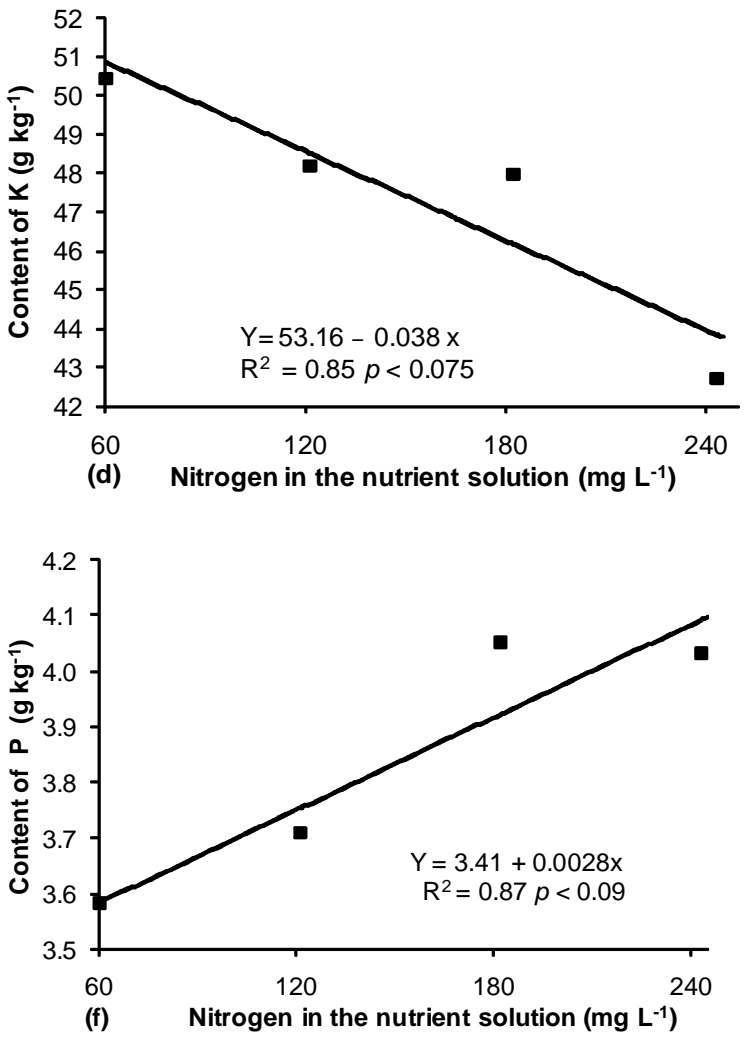

Figure 2 - Contents of N (a), Ca (b), Mg (c), K (d), S (e) and P (f) in leaves dry fitomass of rocket salad for N concentration in the nutrient solution, in the NFT system.

Table 4 - Contents of N, P, K, Ca, Mg and S in leaves dry fitomass of rocket salad cultivars evaluated in the NFT system.

\begin{tabular}{lcccccc}
\hline Cultivars & $\mathrm{N}$ & $\mathrm{P}$ & $\mathrm{K}$ & $\mathrm{Ca}$ & $\mathrm{Mg}$ & $\mathrm{S}$ \\
\hline & $46.3 \mathrm{a}$ & $4.1 \mathrm{a}$ & $54.9 \mathrm{a}$ & $23.1 \mathrm{a}$ & $4.6 \mathrm{a}$ & $3.6 \mathrm{a}$ \\
Cultivada & $41.7 \mathrm{~b}$ & $4.0 \mathrm{a}$ & $43.8 \mathrm{~b}$ & $22.3 \mathrm{a}$ & $4.5 \mathrm{a}$ & $3.4 \mathrm{~b}$ \\
Folha Larga & $39.2 \mathrm{~b}$ & $3.4 \mathrm{~b}$ & $43.3 \mathrm{~b}$ & $31.4 \mathrm{a}$ & $4.3 \mathrm{a}$ & $2.9 \mathrm{~b}$ \\
\hline Selvática & & &
\end{tabular}

Means followed by the same letter within columns are not different (Tukey test, $p<0.05$ ).

Selvática presented the highest nitrate content (1,859.33 $\mathrm{mg} \mathrm{NO}_{3}^{-} \mathrm{kg}^{-1}$ of fresh fitomass) in comparison to Folha Larga and Cultivada, which on the other hand did not differ from each other, with a nitrate content of 1,087.87 and $982.20 \mathrm{mg} \mathrm{NO}_{3}^{-} \mathrm{kg}^{-1}$ of fresh fitomass, respectively. The intraspecific difference for the accumulation of nitrate has also been observed in species of spinach (Spinacia oleracea), lettuce (Lactuca sativa), wild chicory (Cichorium intybus) and others, as reported by 


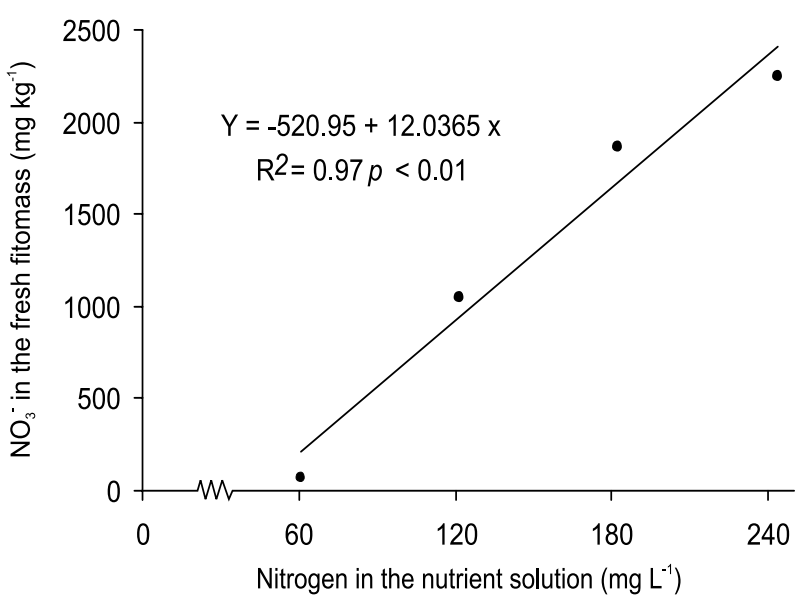

Figure 3 - Nitrate contents in the leaves of rocket salad plants for $\mathrm{N}$ concentration in the nutrient solution, in the NFT system.

Graifenberg et al. (1993); Pilau et al. (2000); Cavarianni et al. (2005).

With regard to the effect of $\mathrm{N}$ concentration on nitrate content, rocket plants with $243.5 \mathrm{mg} \mathrm{N} \mathrm{L}^{-1}$ showed the highest nitrate content $\left(2409.93 \mathrm{mg} \mathrm{kg}^{-1}\right.$ of fresh fitomass) (Figure 3). The adjustment to a linear equation for nitrate content when the amount of $\mathrm{N}$ in the nutritive solution was increased, may be explained by higher absorption of $\mathrm{N}$ by the plant (Figure 2a) without the corresponding increment in dry fitomass (Figure 1d), thus contributing to the establishment of a luxury consumption of this nutrient in the plant. In the case of rocket, this excess of $\mathrm{N}$ reduced the quality of the vegetable as a result of the substantial increase in the leaf nitrate content, which poses a health risk for the consumer. On the other hand, the use of $93 \mathrm{mg} \mathrm{L}^{-1}$ of $\mathrm{N}$ in the nutrient solution, which produced the highest fresh fitomass rated for the leaves (Figure 1b), reduces leaf nitrate content to $598.44 \mathrm{mg} \mathrm{NO}_{3}^{-} \mathrm{kg}^{-1}$ of fresh matter mass (Figure 3), about $75 \%$ less nitrate than that obtained at the highest concentration of $\mathrm{N}$ in the nutrient solution.

\section{CONCLUSIONS}

Increase in the nitrogen concentration in the nutrient solution affected the macronutrient contents in different ways. Cultivar Cultiva produced the best results for the evaluated characteristics, being considered the most appropriate to the home market of Jaboticabal. Increase in the nitrogen concentration in the nutrient solution, however, accounted for the reduction in the quality of the product.

\section{REFERENCES}

BOINK, A.; SPEIJERS, G. Health effects of nitrates and nitrites: a review. Acta Horticulturae, v.563, p.29-36, 2001.

BANZATTO, D.A.; KRONKA, S.N. Experimentação agrícola. 3 ed. Jaboticabal: FUNEP, 1995. 247p.

BATAGLIA, O.C.; FURLANI, A.M.C.; TEIXEIRA, J.P.F.; FURLANI, P.R.; GALLO, J.R. Métodos de análise química de plantas. Campinas: Instituto Agronômico, 1983. 48p. (Boletim Técnico, 78).

CASTEllane, P.D.; ARAUJO, J.A.C. Cultivo sem solo: hidroponia. Jaboticabal: FUNEP, 1994. 43p.

CATALDO, D.A.L.; HAROON, M.; SCHRADER, L.E.; YOUNGS, V.L. Rapid colorimetric determination of nitrate in plants tissue by nitration of salicylic acid. Communication in Soil Science and Plant Analysis, v.6, p.71-90, 1975.

CAVARIANNI, R.L. Teor de nitrato em cultivares de almeirão, cultivadas em hidroponia, em função do horário de colheita. Jaboticabal: UNESP/FCAV, 2002. 46p. Monografia (Trabalho de Graduação).

CAVARIANNI, R.L.; CECÍlIO FILHO, A.B; COELHO, R.L.; CAZETTA, J.O. Teor de nitrato em cultivares de almeirão, cultivados em hidroponia, em função do horário de colheita. Científica, v.33, p.50-56, 2005.

COELHO, R.L. Acúmulo de nitrato e produtividade de cultivares de almeirão em cultivo hidropônico - NFT. Jaboticabal: UNESP/ FCAV, 2002. 67p. Dissertação (Mestrado).

FAQUIN, V.; MARQUES, E.S.; SANTOS, S.H.; DUBOC, E. Crescimento e concentração de nitrato de alface, sob influência da relação $\mathrm{NO}_{3}^{-}: \mathrm{NH}_{4}^{+}$e cloro na solução nutritiva e horário de colheita. In: REUNIÃO BRASILEIRA DE FERTILIDADE E NUTRIÇÃO DE PLANTAS, 21., Petrolina, 1994. Anais. Petrolina: SBCS, 1994. p.152-153.

FURLANI, P.R.; BOLONHEZI, D.; SILVEIRA, L.C.P.; FAQUIN, V. Nutrição mineral de hortaliças: preparo e manejo de soluções nutritivas. Informe Agropecuário, v.20, p.90-98, 1999.

GRAIFENBERG, A.; BORSANTI, L.; BOTRINI, L.; TEMPERINI, O. La problematica dei nitrati. L'Informatore Agrario, v.6, p.43-48, 1993.

MALAVOLTA, E.; VITTI, G.C.; OLIVEIRA, S.A. Avaliação do estado nutricional das plantas: princípios e aplicações. 2 ed. Piracicaba: POTAFÓS, 1997. 319p.

MAYNARD, D.N.; BARKER, A.V.; MINOTTI, P.L.; PECK, N.H. Nitrate accumulation in vegetables. Advances in Agronomy, v.28, p.71-118, 1976.

PILAU, F.G.; SCHIMIDT, D.; SANTOS, O.S.; MANFRON, P.A. Teores de nitrato em cultivares de alface sob hidroponia, na primavera. Horticultura Brasileira, v.18, p.276-277, 2000.

PURQUERIO, L.F.V. Crescimento, produção e qualidade de rúcula (Eruca sativa Miller) em função do nitrogênio e da densidade de plantio. 2005. Available at: http://www.biblioteca.unesp.br/ bibliotecadigital/document/listeses.php?tid=213\&stat=a. Accessed 5 May 2007.

SANTAMARIA, P.; GONNELlA, M.; ELIA, A.; PARENTE, A.; SERIO, F. Ways of reducing rocket salad nitrate content. Acta Horticulturae, v.548, p.529-536, 2001.

TRANI, P.E.; GRANJA, N.P.; BASSO, L.C.; DIAS, D.C.F.S.; MINAMI, K. Produção e acúmulo de nitrato pela rúcula afetados por doses de nitrogênio. Horticultura Brasileira, v.12, p.2531, 1994.

VOLPE, C. Resenha meteorológica do período 1971-2000. Available at: http://www.fcav.unesp.br/departamento/cienciasexatas/ caract/estacao/resenha71_00.htm. Accessed 21 Feb 2006.

$\overline{\text { Received August }}$ 02, 2006

Accepted March 13, 2008 